\title{
Let Rhoda Speak Again: Identity, Uncertainty, and Authority in Virginia Woolf's The Waves
}

\section{ABSTRACT}

Performing a rereading of Virginia Woolf's 1931 experimental modernist masterpiece of The Waves, in this article I focus on the elusive and conflicted character of Rhoda, whose significance has been either overlooked or marginalized in the available criticism of the narrative. By pointing out a number of problems in the existing scholarship devoted to Rhoda, I propose to define her as a transgressive figure of uncertainty through which Woolf develops a critique of the unitary self. My point of departure for the following essay is Toril Moi's perspective on Woolf's oeuvre as openly feminist and deconstructive. Consequently, I begin with Moi's emphasis on Woolf's commitment to the problematization of the Western male humanism's underlying concept of the unitary self. Drawing from a number of critical and philosophical perspectives, I turn to Kim L. Worthington's idea of subjectivity as a sustained process of interpersonal narrativization in order to offer a more nuanced account of Rhoda's identity as compound and implicated in the dynamics of intersubjective processes. I also consider Rhoda's much criticized rejection of identity vis-à-vis Woolf's strategy of impersonality, and, contrasting it with Maurice Merleau-Ponty's phenomenological concepts of the flesh and anonymous existence, I contend that Rhoda renounces the unitary selfhood, which corroborates Moi's critique of Woolf. Through a close analysis of Rhoda's position versus the other characters, as well as by examining how Rhoda's ego boundaries are delineated in the narrative, I demonstrate that Woolf's conflicted heroine emerges as an astute critic of gendered reality, since she is the one who most acutely feels the dualistic nature of selfhood and it is chiefly through her that Woolf points to the need to overcome this dualism. Shannon Sullivan's feminist revision of the Merleau-Pontian perspective on the anonymity and the body as well as the Deweyan notion of transactionality further helps to elucidate 
the ways in which Rhoda's experimental and subversive discourse engages in a polemic with the Cartesian conceptualization of identity presupposed on the dualism of mind and body simultaneously inquiring about a possibility of a non-dualistic and non-unitary conception of subjectivity. As a consequence, Rhoda gains authority and agency through uncertainty which prompts her to adopt an uncompromisingly and insistently questioning stance. Finally, I suggest reconsidering Rhoda's suicide as a metaphorical act of 'distancing,' as discussed by Zygmunt Bauman, via Adorno, in his 2006 Liquid Fear, another context for approaching Rhoda's uncertainty.

\section{Abstract}

It is beyond our reach. Yet there I venture. -Virginia Woolf The Waves

In her introduction to Sexual/Textual Politics tellingly titled "Who's Afraid of Virginia Woolf?" Toril Moi observes that even though Woolf's project "reveals a deeply sceptical attitude to the male-humanist concept of an essential human identity," it has been frequently misconstrued by feminist critics (10). Moi, who identifies deconstruction of the concept of the unitary self as one of Woolf's major preoccupations, further points out that unitary selfhood is a notion central to traditional Western male humanism, a phallic self in disguise, based on an inherently patriarchal assumption that every individual needs to "adopt a unified, integrated selfidentity" (7-8). It is hardly a coincidence that Moi devotes the opening chapter of her book of feminist literary theory to Woolf, whose writing was indeed deeply preoccupied with problematizing the Transcendental Ego $^{1}$ through exposing it as a patriarchal construction, and instead conceived of subjectivity as implicated in a dynamic of intersubjective processes of becoming rather than being. As Roxanne J. Fand remarks in her book The Dialogic Self, in Woolf's time “being a woman was not without

1 In her 2001 study Living Across and Through Skins: Transactional Bodies, Pragmatism, and Feminism, Shannon Sullivan points out that "throughout history of philosophy, philosophers have claimed that there is an essential 'core' in humans that underlies all of their cultural and other differences. Some have called this core 'Reason'; others, 'the Universal Mind'; and still others, 'the Transcendental Ego.”' Sullivan's study questions this tradition by exposing essentialist and patriarchal thinking that stands behind it (73). 
ego boundaries, but rather feeling ego as an imposition, ... empowered for a man, disempowered for a woman" (45, my emphasis). Contributing to the impressive body of available scholarship devoted to Woolf's oeuvre, I would like to propose a reading of her 1931 modernist masterpiece The Waves in the context of a number of critical perspectives that open new avenues for thinking about Woolf's work, and show a commitment on her part to push the writing towards the non-unitary and non-dualistic conceptualization of female identity, as well as its dynamic evolution over time and recuperative potential. One such noteworthy perspective is offered in Kim L. Worthington's Self as Narrative: Subjectivity and Community in Contemporary Fiction, which re-examines a number of the currently debated critical approaches to the question of identity constitution, and effectively tries to overcome the poststructuralist impasse in defining the modern self that has been frequently enough bemoaned as fragmented or theorized along much more dramatic lines as being under the constant threat of complete dissolution. By contrast, Worthington sets out to explore subjectivity as "an active interpretative process"; "a narrative of personal continuity through time" (13). Her project's emphasis on the spatio-temporal dimension of the self reminds us that subjectivity has always been implicated in the larger concept of intersubjectivity, since, as Worthington aptly states, "[o]ne's conception of self is never fixed simply in one permanent structure of representation, but in a plurality of shifting affiliations" (80). Whereas intersubjectivity is undoubtedly an underlying trait of Woolf's entire oeuvre, ${ }^{2}$ it is particularly conspicuous in the experimental narrative of The Waves, where the intertwined planes of spatiality and temporality play a major part in structuring the characters' collective and individual experience. Worthington's approach may serve as a valuable context for rethinking The Waves as a text that is deeply preoccupied with the question of identity in process, which Woolf masterfully articulates through a set of characters whose interrelated soliloquies simultaneously and continuously test the singularity of 'I' in the common world "where many selves come to mingle and depart" (Worthington 165). ${ }^{3}$ As

2 While intersubjectivity is by no means unique to Woolf's oeuvre, I would like to underscore its particular significance in discussing the narrative such as The Waves. As a way of discovering and constructing one's self through the selves of others and "interliving" with others, intersubjectivity is one of the key issues in Woolf's text, and Rhoda is a figure most poignantly grappling with simultaneous conflicting desires for withdrawal into solipsistic individualism and a sense of belonging to the common world of shared meanings.

As a variant of dramatic monologue, soliloquy allows Woolf to avoid the constraints of the third person narration by creating an effect of withdrawal into a mode of narrativity that hinges on the stream of consciousness technique, and simultaneously allows for intersubjectivity through an on-going subconscious dialogue with others. 
Woolf famously observed with a considerable dose of calculated irony in her Letters:

The six characters were supposed to be one. I'm getting old myselfI shall be fifty next year; and I come to feel more and more how difficult it is to collect oneself into one Virginia; even though the special Virginia in whose body I live for the moment is violently susceptible to all sorts of separate feelings. Therefore I wanted to give a sense of continuity. (397)

Indeed, Bernard, Susan, Rhoda, Neville, Jinny, Louis, and Percival form a kind of intersubjective continuum. They are present together on the stage of the world, but as each of them speaks, they are not necessarily always heard or seen by the others. As Worthington would have it, they actively participate in the sustained process of identity constitution through its narrativization over time when they 'interlive,' when they choose separate paths in life, when they are reunited at different points in their lives, and when they continue to coexist through their interrelated narratives even beyond the moment of their lives' closure.

In his compelling study Literary Impressionism and Modernist Aesthetics, Jesse Matz reminds us that in Woolf's work intersubjectivity is always combined with her preoccupation with impersonality, which gave rise to her work's overarching question, resonating particularly strongly in The Waves, of how to "describe the world seen without a self" (287). According to this approach, intersubjectivity and impersonality should not be viewed as contradictory. As it will be explained further in the article, I trace the impersonality that Matz mentions in his study to Merleau-Ponty's idea of anonymity and, to be precise, the anonymous body, which, far from the negative sense of the word, for the phenomenologist implied the impersonal (i.e., shared and prepersonal) level of bodily existence. Matz also explains Woolf's approach to subjectivity by defining it as a conceptual variant of literary Impressionism that emphasizes "a phenomenological link of subject and world" that derives directly from Bergsonian notions of duration and intuition (26). In the chapter titled "Woolf's Phenomenological Impression," Matz underscores her commitment to expressing a whole range of interrelated indeterminacies and differences in mood and feeling, which makes Woolf's Impressionism "a matter of feminist epistemology" (176). For Matz, this literary kind of Impressionism is characterized by the fundamental problem, located somewhere between empiricism and phenomenology, of the radical uncertainty concerning subjectivity and the horror of its complete dissolution (29). Importantly, Matz suggests embracing this particular kind of uncertainty as a vehicle that offers "a range of possibilities" and that turns "dilemmas into options" (18). The potential of uncertainty emphasized by Matz constitutes the core of im- 
pressionist modernist narrative of The Waves, all the more important when considered in the light of Woolf's openly feminist agenda. Uncertainty simultaneously structures and frustrates the world of interconnected selves in Woolf's work. Her characters, perversely described in one of her diary entries as "merely views," are, as Lisa Marie Lucenti observes, always precariously "fluctuating between acceptance and rejection of their own insubstantial nature" (Woolf, The Diary 264; Lucenti 75). The "seamlessly unified self," to resort to Moi's phrase again, is constantly questioned and deconstructed by all the characters of The Waves; in particular, it is the elusive figure of Rhoda that emerges as Woolf's main vehicle for articulating the above delineated concerns (Moi 8). In its focus on Rhoda's uncertainty and its precarious potentiality, this essay is based on a risky wager that the poignantly fragile self-effacing female character, whose performance is enacted through a number of fearful soliloquies to finally end in a suicidal flight long before the closure proper of the book, is part and parcel of Woolf's feminist project of reconceptualization of female identity that Moi chooses as a point of departure for her own argument in the opening lines of Sexual/Textual Politics. It is my contention that Rhoda's significance needs to be reconsidered in the light of textual evidence and critical contexts that are more sympathetic to the ambivalence that her complex character embodies.

While the available criticism of The Waves has not been entirely indifferent to Rhoda, she does not feature prominently in the scholarship devoted to the narrative. Indebted as I certainly am to a vast number of studies that offer significant analyses of the dilemma of the subject in The Waves and in Woolf's oeuvre in general, I find their characterizations of Rhoda reductive, if not entirely dismissive. Just to give a brief overview, Gabrielle Schwab's essential chapter on The Waves coming from her book Subjects Without Selves deploys the Kristevan theoretical model of the subject-in-process/on trial and develops as a way of critiquing the reductiveness of the idea of the death of the subject. Schwab, however, fails to see that it is chiefly through Rhoda that Woolf articulates her views on the subject-in-process/on trial, and this oversight causes her to define Rhoda as a character "remain[ing] emotionally imprisoned in herself" who betrays the "psychotic dissolution of the body" $(77,75)$. Schwab suggests that the narrative of The Waves merely "prepares the way for later, less dichotomous presentations of subjectivity," as if ignoring the fact that these preoccupations are already present in Woolf's 1931 work, and finally ends her analysis on a dubious note asking whether Rhoda could be seen as "the intrusion of the real" (92). In Virginia Woolf and the Problem of the Subject, Makiko Minow-Pinkney, whose critique also relies on the Kristevan model of subjectivity, argues that Rhoda is "incapable of establishing the thetic subject" and remains 
fearfully suspended between the "denial of unity" and "the agony of the fragmented self” $(163,169)$. Minow-Pinkney's largely mistaken underlying idea of the fragmentariness as an essential trait of the text's temporality and the fractured self of Rhoda is the major weakness and limitation of this otherwise important analysis. Another critical examination of The Waves, coming from Judy Little's Kristevan/Bakhtinian study titled The Experimental Self, attempts to characterize Rhoda in a more positive and productive way as a figure who defines herself in creative and transformative appositional relation to others, rather than being in opposition to them, and remains in "an ambivalent relation to the symbolic order" (66). Roxanne J. Fand's Bakhtinian reading of Rhoda included in her book The Dialogic Self proposes a more promising and complex notion of the self oscillating between unity and diversity suggesting that Rhoda is "a nomadic character" whose high level of self-awareness helps her develop a consciously ironic stance toward the worldly order and ultimately renounce the world in the spirit of Nietzschean 'will-to-power' (60). In Fand's view, however, Rhoda's "discourse of violence and will to power" are "the underside of her pathetic helplessness," which gives her analysis of Rhoda chiefly negative inflections (90). Few of the existing analyses demonstrate sensitivity to the critical role Rhoda plays in the narrative. Instead, in spite of their commitment to the deconstructive strategy of reading, they often stop at the disappointingly reductive literal interpretation of Rhoda's death, reading it as her failure, rather than a refusal, to develop a sense of unified selfhood through entering the social sphere. Preoccupied as these analyses undoubtedly are with Woolf's efforts to challenge the unitary notion of selfhood, they still appear to hold on to the traditionally sanctioned notion of the Cartesian self, and contradict the deconstructive goal of their projects by failing to see Rhoda as a key figure in Woolf's oeuvre in general, and by mistaking Rhoda's tacit transgression for resignation and inability to integrate into society.

I would like to challenge the ways in which Rhoda's conflicted figure has been viewed in the text's available interpretations; her significance largely reduced by her apparently marginal status relative to other characters of The Waves and, more directly, by her suicide. In contrast to the majority of readings that offer chiefly negative interpretations of Rhoda emphasizing failure as her indelible trait, and writing her off as a dysfunctional psychotic character, I would like to approach Rhoda as a complex figure of uncertainty and at the same time Woolf's vehicle for articulating a profound recognition of the necessity to challenge the dualistic thinking underlying the rigidly defined contours of the Transcendental self. In the following pages, Rhoda will be examined as a character through which Woolf radically destabilizes the boundaries of the ego through exposing 
and renouncing the conception of unitary selfhood. In my interpretation, I will rely on Worthington's concept of narrativization of the self, Maurice Merleau-Ponty's anti-dualistic notion of the flesh of the world developed in his unfinished work The Visible and the Invisible, Shannon Sullivan's feminist revision of Merleau-Ponty's phenomenological project as well as her deployment of the concept of transactionality (via John Dewey), and finally Zygmunt Bauman's insightful reflections on the modern-day uncertainty coming from his 2006 work Liquid Fear, all of which provide crucial insights into Woolf's extraordinary commitment to narrativization of female identity and to the feminist agenda in general. In the following analysis, Rhoda will be examined primarily as a liminal figure that embodies Woolf's uncertainty regarding the boundaries of the Transcendental Ego presupposed on the Cartesian dualism of mind and body.

As Judy Little aptly observes in passing in her study The Experimental Self, the complex character of Rhoda is "a radical and experimental voice" expressive of the Woolfian discourses that "do not fit into a scheme of binary difference" $(68,37)$. Indeed, whereas the female characters in The Waves are constantly questioning their positions in gendered reality, they do so predominantly within strictly defined boundaries of the social roles available to them; Jinny questions the social constructions of femininity, whereas Susan finds little reconciliation between her individual freedom and motherhood. Rhoda, on the other hand, noticeably surpasses Jinny and Susan in trying to articulate her uncertainty about these two socially acceptable models of femininity, portrayed by Woolf as inscribed in essentialist realizations of female identity. Unlike Jinny and Susan, Rhoda not only refuses to subscribe to either of these two orders traditionally constitutive of female identity, but also becomes painfully aware of the fact that no in-between position in the biologically determined essentialist binary (i.e. mother versus beloved) regulating the normative conceptualization of femininity is available to her. At the same time, however, as a character who most of the time perceives the world and others from the distance of self-imposed detachment, Rhoda is granted a considerable, if not striking, degree of authority and insight. In the following sections of this essay, I will closely examine her position in the social space relative to the other characters, as well as her own perception of that position, with a particular emphasis on the dynamics between the interiority of the mind and the body, and finally, by extension, the dynamics between the socially structured inside and its outside; the dualisms that Rhoda insistently questions throughout the narrative.

In order to put the complexities of Rhoda's conflicted position concerning the mind versus body dualism in perspective, one might want to turn at this juncture to Merleau-Ponty's phenomenology of perception 
and his notion of flesh formulated in his unfinished The Visible and the Invisible. Merleau-Ponty describes the flesh of the world as a non-dualistic form of being that he refers to as a "less heavy, more transparent body" presupposed on the balance between the psychical and physical dimension of our coexistence in the world, and constitutive of the sustaining tissue of the world (153). Along the same lines, in the Woolfian interworld of selves the flesh of the world is woven out of the characters' mutual transactions ${ }^{4}$ occurring on the plane where the psychical and the corporeal are interrelated: "But when we sit together, close," as Bernard says in the narrative, "we melt into each other with phrases. We are edged with mist. We make an unsubstantial territory" (16). For Merleau-Ponty, the notion of flesh is presupposed on the pre-personal anonymity that ensures the common ground for our intersubjective processes. For Woolf, similarly, the characters are enmeshed in the invisible yet almost palpable sustaining tissue in and through which they interlive with one another, and which makes their own presence possible and recognizable to themselves and others. Nonetheless, while they all share the feeling of belonging to the common interworld of selves, Rhoda, like the solitary chirping bird spotted by the bedroom window at the beginning of the narrative of The Waves, resolutely chooses not to sing "in chorus" despite her acute awareness of belonging to the flesh of the world (10). Instead, she creates her own imagined reality in which she nominates herself the captain of her little fleet of white petals in a brown basin:

I have a short time alone ... I have a short space of freedom. And I will now rock the brown basin from side to side so that my ships may ride the waves. Some will founder. Some will dash themselves against the cliffs. One sails alone. That is my ship ... They have scattered, they have foundered, all except my ship which mounts the wave and sweeps before the gale and reaches the islands where the parrots chatter and the creepers... (19)

The way in which little Rhoda envisions the future of her petal fleet early in The Waves, clearly an allegorical enactment of her life among the other characters, is significant not only because it adumbrates the different and often interconnected trajectories of her friends' life-stories, but also

\footnotetext{
4 I borrow the concept of "transaction" from Sullivan's 2001 study, in which she deploys the term, via American pragmatist philosopher John Dewey, to account for "the dynamic, co-constitutive relationship of organisms and their environments . . . [and to reflect] a rejection of sharp dualisms between subject and object, and self and world, as well as a rejection of the atomistic, compartmentalized conceptions of the subject and self that often accompany such dualisms" (1).
} 
because of the imaginative power with which she emphatically depicts her solitary ship's exotic voyages, privileging her brave future over the precarious fates of others. This early image of Rhoda dreaming of becoming the captain of the ship, later frequently evoked by others, is followed by moments during which she dreamily ventures past "the ordinary scene" towards dangerous seas, and even the distant land of India, where her beloved Percival goes and accidentally dies (197). Rhoda's occasional surges of self-confidence, while always largely conditioned upon her detachment from her friends and shot through with the awareness that "[riding] rough waters [she] shall sink with no one to save [her]" clearly point to her subversive nature (160). Her recurring dreams of adventures and leadership, however, can only remain impossible fantasies created in the safety of her self-imposed solitude to be immediately thwarted by the confines of gendered social reality, where such brave feats are reserved for men. While Rhoda rejects the conventional femininity and "prettiness" that underpin the socially constructed notion of womanhood, she also realizes that she will continue to be perceived as a young woman inhabiting gendered social spaces, which she sums up with a blunt observation: "I'm also a girl, here in this room" $(160,107)$.

Once Rhoda becomes aware of the social, spatial and temporal boundaries of her ego, she will continue her narrativization of identity, to use Worthington's phrasing, almost exclusively through depersonalization, repeatedly rejecting the Transcendental Ego that in Woolf's text emerges unmistakably as a phallic imperialist self, and that the characters of The Waves simultaneously insistently question and identify with, which can be seen in their almost worshipful attachment to Percival. As Helen Wussow notes in her 1998 book on Woolf and D.H. Lawrence The Nightmare of History, Percival is the one who embodies "the self-centred imperialism" that the author of The Waves mockingly exposes (111). It is through one of Rhoda's powerful soliloquies that Woolf shows the characters' desire to identify with the unitary self such as Percival's: "I am nobody. I have no face. This great company, all dressed in brown serge, has robbed me of my identity ... I will seek out a face, a composed, a monumental face, and will endow it with omniscience, and wear it under my dress like a talisman ...” (33). Percival's tragic demise in India deeply affects Rhoda, not only because of her love for him, but rather because his death paradoxically makes her feel all the more self-conscious and vulnerable by forcing her into a collective experience of mourning. Importantly, it also amplifies the contrast between her fearful vulnerability and low self-esteem and his grandeur that remains unquestioned by others, except by Woolf herself, and is continuously expressed by the other characters before and after he dies. The fact of Rhoda and Percival's mutual affection notwithstanding, the contrast between her 
fragility and his towering figure is indeed striking. However, it is also worth observing that there exists another interesting affinity between those two in how they both aspire to authority; Percival claims it in the outside world (it is significant that we only know of him through other people's voices, but we never hear him speak) while Rhoda strives to achieve it both externally and internally. For all her withdrawal and introversion, she makes her presence intensely felt throughout the narrative, and there is an uncanny sense of urgency every time we read Rhoda's soliloquies. Her every social appearance is always commented on by others and she is frequently described as a "wild" mercurial figure "one never could catch"; someone who tried to see past the familiar horizon beyond which the others' gaze did not venture (247). Simultaneously, desperately trying to stabilize her sense of selfhood in the face of severely limited ambitions, Rhoda feels that her fleeting uncertain image can be fixed only momentarily, and insofar as it is contrasted with and mediated through others' stable identities:

That is my face ... in the looking-glass behind Susan's shoulder-that face is my face. But I will duck behind her to hide it, for I am not here. I have no face. Other people have faces; Susan and Jinny have faces; they are here. Their world is the real world. The things they lift are heavy. They say Yes, they say No; whereas I shift and change and am seen through in a second. (43, my emphasis)

Unlike her friends, whose selves are securely stabilized by the social roles they choose to adopt, Rhoda is torn between her latent desire to preserve the autonomy of her dynamic and changeable instable identity and the simultaneous fear of identity dissolution, which keeps pushing her back towards some safe anchorage in the fabric of social reality:

'If I could believe ... that I should grow old in pursuit and change, I should be rid of my fear. ... I have no end in view. I do not know how to run minute to minute and hour to hour, solving them by some natural force until they make the whole and indivisible mass that you call life. Because you have an end in view-one person, is it, to sit beside, an idea is it, your beauty is it? ... But since I wish above all things to have lodgment, I pretend ... to have an end in view ... I wait for you to speak like you. I am drawn here across London to a particular spot, to a particular place, not to see you or you or you, but to light my fire at the general blaze of you who live wholly, indivisibly and without caring in the moment. (130-31)

Acutely aware of the constructed and dualistic nature of subjectivity, whose underlying primacy of mind over body becomes the main source of her anxiety and uncertainty throughout the narrative, she is constantly 
driven by the fear of the impermanence and vulnerability of the body. Not surprisingly, therefore, she finds relief during moments of "the disembodied mood" surrounding her and others, and often articulates a wholesale disavowal of corporeality (228). Unlike the other characters who remain attached to the vicissitudes of ordinary experience, and are in different ways constrained by their bodies and language, Rhoda's troubled introspection, and significantly also extrospection, since she is conspicuously and obsessively preoccupied with the inside and outside reality, cannot be readily dismissed as failures to either fit in or transact with others. To understand Rhoda's fear, we have to see her as someone who inhabits a world defined by dualistic thinking, a reality that compartmentalizes her world and her identity into subject and object positions, male and female gender, as well as disconnected realities of mind and body, where the former component of each binary is clearly privileged. Rhoda is the only character in The Waves who, extremely sensitive to the firmly rooted belief in the dualistic conception of selfhood with its socially enforced irreconcilable split into mind and body, confronts a possibility of the non-dualistic nature of identity envisioned as a continuous dynamic Möbian-like relationality occurring between the activity of the mind and the activity of the body. Throughout the narrative of The Waves, Rhoda gradually and fearfully comes to understand what it means for her to step both inside and outside of "the loop" of social performativity. Her solitary and intensely intro-/extrospective quest is informed by a desire for and a simultaneous fear of fluidity of identity and experience, as well as their transgressive nature. She dreams of existence as an immanent plane devoid of "hard contacts and collisions," and reflects: "[m] onth by month things are losing their hardness; even my body now lets the light through; my spine is soft like wax near the flame of the candle" (45). Rhoda's uncannily strong affinity with the imagery of water and fluidity is always shot through with anxiety and uncertainty coming from a constant clashing of the need for the reassuring solidity and clearly distinguishable palpable contours of identity on the one hand, and a simultaneous confrontation of their fluid permeable boundaries and the outside reality on the other. Characteristically, Rhoda's relief at the feeling of "the walls of the mind becom[ing] transparent" communicates not only the mind's coming into contact with external reality, but also its capability to discern and evaluate life's socially constructed colonizing structure: "Wren's palace, like the quartet played to the dry and stranded people in the stalls, makes an oblong. A square is stood upon the oblong and we say, "This is our dwelling-place. The structure is now visible. Very little is left outside'” (228). The insight gained by this moment of heightened perception is that the interiority of the mind is overcome through her senses and therefore also through her body towards 
the outside. It is only through an ongoing transactionality between herself and others, between the inside and outside, that she can experience social spaces and boundaries between emerging shapes, objects, bodies, and thoughts, and come closer to a profound realization of how both the mind and body equally participate in her perception of reality and constitute her subjectivity. Of all the characters in The Waves, Rhoda is particularly sensitive and vulnerable to how the materiality of the outside physical reality, the physical boundaries of the body, and the interiority of the mind are violently drawn into relation, which is something that she simultaneously desires and fears. One of the central images of the narrative is the scene in which Rhoda's fear is exacerbated by the fear of fluidity that threatens a complete dissolution of identity:

'There is the puddle,' said Rhoda, 'and I cannot cross it. I hear the rush of the great grindstone within an inch of my head. Its wind roars in my face. All palpable forms of life have failed me. Unless I can stretch and touch something hard, I shall be blown down the eternal corridors for ever. What then can I touch? What brick, what stone? And so draw myself across the enormous gulf into my body safely? (158-59, my emphasis)

In this powerful scene, Rhoda is paralyzed by the horror of the physical and material 'palpable' reality slipping away from her grasp, but also the horror prompted by a recognition that her sense of identity depends on the physical contact with the "palpable forms of life." She feels disembodied and unable to identify with her own body, which turns out to be frightfully incapacitating. At the same time, she is also overcome by the abysmal fear of the suddenly unfamiliar outside reality, whose only certainties are the liquid reality of the puddle and instability of the brittle objects within her reach (brick and stone) that further threaten Rhoda's precarious position. Her identity can be stabilized by the return to the body, as the last line of the quoted passage clearly demonstrates. The puddle, which in her perception grows to enormous proportions, becomes a contentious site of ambivalence concerning a desire to regain control over the materiality of the body and the simultaneous horror of questioning her own corporeality and thereby losing grasp of the physical and the material, another symbol of Rhoda's fear. Another crucial element related to corporeality that is present in the puddle scene is the sense of touch, which transpires in Rhoda's repeated references to it. The body might be another source of uncertainty for her, but she simultaneously, if subconsciously, firmly relies upon its properties. She knows that she needs to touch the objects in her vicinity to be saved from falling into "the enormous gulf" that the puddle appears to her to be. This key passage also points to the significance of spatial and 
temporal boundaries that deeply affect Rhoda's ways of perceiving herself, others, and the surrounding reality.

In order to look more broadly at Rhoda's perspective on the intertwined planes of social spatiality and temporality we need to return to her schoolage activity of figure-drawing, which betrays both her fear of containment and a simultaneous terror of inhabiting the outside of socially constructed time and space: "Look, the loop of the figure is beginning to fill with time; it holds the world in it. I begin to draw a figure and the world is looped in it, and I myself am outside the loop; which I now join-so-and seal up, and make entire. The world is entire, and I am outside of it, crying, 'Oh, save me, from being blown for ever outside the loop of time!”' (22). Rhoda's peculiar manner of describing various social spaces and situations, always intensely abstract and based on sharp spatial contrasts between geometric figures and their shapes, with a strong emphasis on their contours and the boundaries between them, brings into focus her, and the narrative's, major dilemma of the dualistic nature of reality and subjectivity. The apparently irreconcilable conflict between inside and outside and the drama of disembodied identity are played out through Rhoda, and it is Rhoda's external and internal struggle that brings the problem of the amputated corporeality into focus in The Waves. It also calls for a reconsideration of Woolf's well-known emphasis on impersonality and intersubjectivity and Rhoda's critical role in effecting a difference in how these concepts could be approached.

At this juncture, I would like to return briefly to Merleau-Ponty's idea of the flesh, and an interesting and important intersection that I see between his and Woolf's preoccupation with the common interworld of selves. For the philosopher, what lies at the foundation of the transgressive notion of the flesh is of course the idea that it is primarily the body, and not the mind, the primacy of which Merleau-Ponty's late project tries to overcome, that underlies our mutual transactions occurring in the tissue of anonymous existence. As Shannon Sullivan explains in her analysis of Merleau-Ponty's late work, "anonymous existence is that unnamed and perhaps unnameable level of bodily existence that is prepersonal ... Complementary to the characterization of anonymous existence as prepersonal is Merleau-Ponty's description of it as impersonal ... because the other's 'living body has the same structure as mine" (69-70). Nevertheless, Sullivan hastens to revise the Merleau-Pontian perspective arguing that "[b] odies cannot be appealed to as some sort of foundational 'given' that easily solves the problem of communicating across their differences" (71). In other words, intersubjectivity becomes problematic when presupposed exclusively on the idea of anonymous existence, neutrality of the body, and impersonality. Needless to say, it is precisely the neutral perspective on the body that becomes one of the targets of Sullivan's pragmatist feminist critique. What is brought to 
the foreground in her rereading of Merleau-Ponty is, among other things, the specificity and particularities of gender. Along these lines, I would like to argue that in Woolf's feminist project, the conflicted figure of Rhoda makes a much needed fissure in the impersonal intersubjective continuum of selves whose differences are overcome through their arrival at a realization of their own mortal nature and the idea of the eternal return poignantly emphasized in the narrative's conclusion. Torn between the contradictory desires of embracing the common consciousness of the Transcendental Ego and testing the boundaries of identity and the limits of difference, Rhoda finally renounces her corporeality and gender identity, and with them also her life, not so much because she is ultimately convinced that the fact of embracing these aspects of subjectivity would make little difference in the general scheme of things, or even that their acceptance would push her deeper into already heavily gendered social reality, but because the level of awareness that she arrives at is too radical to be readily and immediately embraced, and because it opens up a precarious territory that seems to her too dangerous and overwhelming.

Finally, through the conflicted figure of Rhoda, Woolf also creates a female character whose transgressive identity prefigures the modern-day state of anxiety that according to social theorist Zygmunt Bauman characterizes post-modernity. In his 2006 compelling study of "liquid fear," Bauman writes:

Fear is at its most fearsome when it is diffuse, scattered, unclear, unattached, unanchored, free floating, with no clear address or cause; when it haunts us with no visible rhyme or reason, when the menace we should be afraid of can be glimpsed everywhere but is nowhere to be seen. 'Fear' is the name we give to our uncertainty... (2)

Characteristic of post-modernity rather than Woolf's modernity, Bauman's paradoxical conceptualization of "liquid fear" as simultaneously escaping clear definition and easily traced to a number of present-day dangers nonetheless emerges as a fundamental trait of Rhoda's uncertainty. Even though Woolf deliberately does not give the readers easy explanations of Rhoda's fears or any explicit key to her conflicted nature, it is not hard to deduce that the major horror she faces is having her identity pre-defined, reified, and finally dissolved in the grey faceless crowd:

Life, how I have dreaded you ... oh, human beings, how I have hated you! How you have nudged, how you have interrupted, how hideous you have looked in Oxford Street, how squalid sitting opposite each other staring in the Tube! Now as I climb this mountain, from the top of which I shall see Africa, my mind is printed with brown-paper parcels 
and your faces. I have been stained by you and corrupted. You smelt so unpleasant, too, lining up outside door to buy tickets. All were dressed in indeterminate shades of grey and brown, never even a blue feather pinned to a hat. None had the courage to be one thing rather than another. What dissolution of the soul you demanded in order to get through one day, what lies, bowings, scrapings, fluency and servility! (203-04)

Terrified of being engulfed by the anonymous crowd, the usually selfeffacing Rhoda occasionally longs for individuality and difference. And here lies the greatest difficulty of approaching Woolf's views on impersonality and intersubjectivity; Rhoda embodies the feminist dilemma of how to sustain a sense of non-unitary identity without subscribing to its predefined sources and without having it stabilized or reified by others. What saves Rhoda's autonomy and at the same time endows her with a considerable degree of authority is her insistently self-conscious and questioning introverted stance along with her strategic approach to reality. As she says at one point, "But it is only that I have taught my body to do a certain trick. Inwardly I am not taught" (222).

As Bernard observes, Rhoda chooses "intense abstraction" because she fears others and the ways in which they "shatter the sense of being which is so extreme in solitude" (133). Indeed, Rhoda is frequently perceived as a kind of 'absent presence'; while the other characters often remark that Rhoda is always clumsily "lagging behind" the rest, she is quite literally "not with them" throughout most of the narrative, but rather occupies an unidentified space beyond all of them, and is often seen as "looking past" or "through" others $(40,12)$. Rhoda's "strange communications when she looks past [others]" suggest a different kind of knowledge that none of the characters are privy to (98). Contrary to what most critics have said about Rhoda's self-destructive fear and its culmination in the "suicidally solipsistic flight" from socially constructed existence, her radical withdrawal does not need to be construed literally as a cowardly instance of escapism, but rather figuratively, as a conscious gesture of a self-aware individual who withdraws in order to identify a different mental space that, in this case, allows for reconsideration and transformation of the traditionally conceived selfhood (McGavran 67). In Liquid Fear, Bauman speaks about such indispensable 'distancing' turning to Adorno's idea of the intellectual who withdraws into "inviolable isolation":

Keeping a distance, paradoxically, is an act of engagement-in the only form which engagement on the side of unfulfilled or betrayed hopes may sensibly take: 'The detached observer is as much entangled as the active participant; the only advantage of the former is insight into his entanglement, and the infinitesimal freedom that lies in knowledge as such.' (173) 
Along similar lines, Rhoda's withdrawal can perhaps be seen as an act of engagement and a way of acquiring knowledge of the sources and consequences of her fear and anxiety. Rhoda's largely unaccounted-for suicide that Woolf merely hints at through the voices of other characters, or rather, to use Annette Oxindine's more sensitive word, her "disappearance," needs to be reconsidered as an act of transgression of the confining social order that is exposed in The Waves through her powerful insights (Oxindine 203). Rhoda is an outsider, an "authentic," as Bernard once referred to her, who "exist [s] most completely in solitude" (116). She is also the one who "ha[s] no end in view"; her uncertainty, connected with remaining fearfully and painfully, yet not without a reason, "unattached, without anchorage anywhere, unconsolidated," indeed becomes the only attainable freedom that the difficult knowledge of the boundaries of selfhood entails (122). Relinquishing the Transcendental Ego, 'the damned egotistical self' of which Woolf was so weary, Rhoda, like artists Lily Briscoe from Woolf's 1927 To the Lighthouse or Miss La Trobe from her final 1941 work Between the Acts, reemerges as a transgressive voice of the feminist intellectual who ushers in change, invites contradiction and ambiguity, and whose powerful discourse subverts the neutral anonymity of the flesh of the world deconstructing it, which, as Moi aptly describes Woolf's textual practice, indeed "leav[es] the critic no single unified position but a multiplicity of perspectives to grapple with" (3). Desperately interrogating her precarious position in the social order, Rhoda paradoxically remains a fragile yet powerful figure of uncertainty through which Woolf voices a desire for difference, and whose withdrawal should be read as a radical rejection of unitary subjectivity presupposed on the mind-body dualism. "Let Rhoda speak," therefore, "whose face I see reflected mistily in the looking-glass opposite; Rhoda [who was] interrupted when she rocked her petals in a brown basin... She is not giddy when she looks down. She looks far away over our heads, beyond India” (138).

\section{WORKS CITED}

Bauman, Zygmunt. Liquid Fear. Cambridge: Polity, 2006.

Bergson, Henri. The Creative Mind: An Introduction to Metaphysics. Trans. by Mabelle L. Andison. Mineola, NY: Dover, 2007.

Fand, Roxanne J. The Dialogic Self: Reconstructing Subjectivity in Woolf, Lessing, and Atwood. Selinsgrove: Susquehanna University Press, 1999.

Little, Judy. The Experimental Self: Dialogic Subjectivity in Woolf, Pym, and Brooke-Rose. Carbondale: Southern Illinois University Press, 1996.

Lucenti, Lisa Marie. "Virginia Woolf's The Waves: To Defer that 'Appalling Moment.” Criticism 40.1 (1998): 75-98. 
Matz, Jesse. Literary Impressionism and Modernist Aesthetics. Cambridge: Cambridge University Press, 2001.

McGavran, James Holt, Jr. "Shelley, Virginia Woolf, and The Waves: A Balcony of One's Own." South Atlantic Review 48.4 (1983): 58-73.

Merleau-Ponty, Maurice. The Visible and the Invisible. Trans. Alphonso Lingis. Evaston: Northwestern University Press, 1968.

Minow-Pinkney, Makiko. Virginia Woolf and the Problem of the Subject. New Brunswick: Rutgers University Press, 1987.

Moi, Toril. Sexual/Textual Politics. London: Routledge, 1985.

Oxindine, Annette. "Rhoda Submerged: Lesbian Suicide in The Waves." Virginia Woolf: Lesbian Readings. Ed. Eileen Barrett and Patricia Cramer. New York: New York University Press, 1997. 203-21.

Schwab, Gabrielle. Subjects Without Selves: Transitional Texts in Modern Fiction. Cambridge: Harvard University Press, 1994.

Sullivan, Shannon. Living Across and Through Skins: Transactional Bodies, Pragmatism, and Feminism. Bloomington: Indiana University Press, 2001.

Vandivere, Julie. "Waves and Fragments: Linguistic Construction as Subject Formation in Virginia Woolf." Twentieth Century Literature 42.2 (1996): 221-33.

Woolf, Virginia. The Diary of Virginia Woolf. Ed. Anne Oliver Bell with Andrew Mc Neillie. 5 vols. New York: Harcourt, 1977-84.

---. The Letters of Virginia Woolf. Ed. Nigel Nicolson and Joanne Trautmann. 6 vols. New York: Harcourt, 1977-82.

---. The Waves. New York: Harcourt, 1931.

Worthington, Kim L. Self as Narrative: Subjectivity and Community in Contemporary Fiction. Oxford: Clarendon, 1996.

Wussow, Helen. The Nightmare of History: The Fictions of Virginia Woolf and D.H. Lawrence. Bethlehem, PA: Lehigh University Press, 1998. 